\title{
Genetic Detection of Neospora caninum in the Blood of Dairy Cattle from Boyacá, Colombia
}

\author{
Detección genética de Neospora caninum en sangre de ganado lechero de Boyacá, \\ Colombia
}

\section{Detecção genética de Neospora caninum no sangue do gado leiteiro de Boyacá, Colômbia}

\author{
Tania-Alejandra Correa-Castro ${ }^{1}$ \\ Andrés-Mauricio Gómez-Palacio ${ }^{2}$ \\ Martin-Orlando Pulido-Medellín ${ }^{3}$ (D)
}

Received: december 2020

Accepted: april 2021

How to cite: Correa-Castro, T. A., Gómez-Palacio, A. M. y Pulido-Medellín, M. O. (2021). Genetic Detection of Neospora caninum in the Blood of Dairy Cattle from Boyacá, Colombia. Revista Científica, 41(2), 252-263.

https://doi.org/10.14483/23448350.17538

\begin{abstract}
Neospora caninum is a parasite of the phylum Apicomplexa that causes significant economic losses for cattle husbandry worldwide. Despite its relevance, information regarding infection prevalence in endemic areas of Colombia is scarce. Previous studies have reported a high seroprevalence in dairy cattle from Boyacá, which suggests a significant risk factor for active transmission of neosporosis. However, there is no available data concerning the infection stage or the presence of said parasite in the peripheral blood of dairy cattle. In this study, genetic detection of $N$. caninum was carried out using a nested PCR with an Nc-5 marker on peripheral blood samples from dairy cows in the municipalities of Paipa, Toca, and Tuta. Four positive
\end{abstract}

samples were sequenced through the Sanger method, which were then edited, aligned, and compared to sequences available in the GenBank database. The parasite's DNA was detected in 23 out of 170 analyzed blood samples. A qualitative detection limit was estimated ( 64 parasites per volume of blood sampled). This is the first report of DNA detection of $N$. caninum through PCR in blood from Colombian dairy cattle. Thereupon, further studies about $N$. caninum molecular detection and population genetics in cattle peripheral blood could be very useful for the early diagnosis of neosporosis and creating more effective epidemiological surveillance strategies.

Keywords: dairy cattle; genetics; molecular detection; nested PCR; neosporosis.

1. M. Sc. Universidad Pedagógica y Tecnológica de Colombia. Tunja, Colombia. tania.correa@uptc.edu.co.

2. Ph. D. Universidad Pedagógica y Tecnológica de Colombia. Tunja, Colombia. andres.gomez04@uptc.edu.co.

3. M. Sc. Universidad Pedagógica y Tecnológica de Colombia. Tunja, Colombia. martin.pulido@uptc.edu.co. 


\section{Resumen}

Neospora caninum es un parásito del filo Apicomplexa que genera grandes pérdidas económicas para la ganadería a nivel mundial. A pesar de su importancia, la información sobre la prevalencia de infección en áreas endémicas de Colombia es escasa. Estudios previos han reportado una alta seroprevalencia en ganado lechero de Boyacá, que sugiere un factor de riesgo significativo para la transmisión activa de la neosporosis. Sin embargo, no hay datos disponibles sobre el estado de infección o la presencia del parásito en la sangre periférica del ganado lechero. En este estudio, se realizó la detección genética de $N$. caninum por PCR anidada del marcador $\mathrm{Nc}_{\mathrm{C}} 5$ en muestras de sangre periférica de vacas lecheras de los municipios de Paipa, Toca y Tuta. Se secuenciaron cuatro muestras positivas por el método de Sanger, que se editaron, alinearon y compararon con secuencias disponibles en la base de datos GenBank. Se detectó el ADN del parásito en 23 de las 170 muestras de sangre analizadas. Se estimó un límite cualitativo de detección en las muestras ( 64 parásitos por volumen de sangre muestreada). Este es el primer reporte de detección del ADN de $N$. caninum por PCR en sangre de ganado lechero colombiano. Por lo tanto, futuros trabajos sobre la detección molecular y la genética poblacional de $N$. caninum en sangre periférica de ganado podrían ser muy útiles para el diagnóstico temprano de la neosporosis y la creación de estrategias más efectivas de vigilancia epidemiológica.

Palabras clave: detección molecular; ganado lechero; genética; neosporosis; PCR anidada.

\section{Resumo}

Neospora caninum é um parasita do filo Apicomplexa que causa perdas econômicas significativas para o gado em todo o mundo. Apesar de sua relevância, as informações sobre a prevalência de infecções na Colômbia em áreas endêmicas são escassas. Estudos anteriores relataram uma alta seroprevalência no gado leiteiro de Boyacá, o que sugere um fator de risco significativo para a transmissão ativa da neosporose bovina. Entretanto, não há dados disponíveis sobre o estágio de infecção ou a presença do referido parasita no sangue periférico do gado leiteiro. Neste estudo, realizou-se a detecção genética de $N$. caninum por meio uma PCR aninhada com um marcador Nc-5 em amostras de sangue periférico de vacas leiteiras nos municípios de Paipa, Toca e Tuta. Quatro amostras positivas foram sequenciadas através do método Sanger, que foram então editadas, alinhadas e comparadas com as sequências disponíveis no banco de dados do GenBank. O DNA do parasita foi detectado em 23 das 170 amostras de sangue analisadas. Foi estimado um limite de detecção qualitativa ( 64 parasitas por volume de sangue amostrado). Este é o primeiro relatório de detecção de DNA de N. caninum através de PCR em sangue de gado leiteiro colombiano. A partir dessas evidências, estudos adicionais sobre a detecção molecular de $N$. caninum e genética populacional no sangue periférico do gado poderiam ser muito úteis para o diagnóstico precoce da neosporose e para a criação de estratégias de vigilância epidemiológica mais eficazes.

Palavras-chaves: detecção molecular; gado leiteiro; genética; neosporose; PCR aninhado.

\section{Introduction}

Neospora caninum is a cyst-forming obligate intracellular parasite belonging to the phylum Apicomplexa (subclass: Coccidia), which infects a wide variety of domestic and wild hosts worldwide (Dubey, 2003). This parasite is the etiological agent for neosporosis, a serious disease in cattle that causes causing major reproductive problems such as abortion and stillbirth (Dubey and Schares, 2006). Studies about N. caninum infection prevalence aimed at reducing the impact on livestock production are considered essential, given that this condition causes huge economic losses in dairy cows/livestock farming worldwide (Dubey et al., 2007).

Serological-based methods and immunohistochemical staining are the most common techniques for detecting $N$. caninum infections in cattle and several hosts, as evidenced by an increasing amount of studies in countries from Africa (Amdouni et al., 2018), Asia (Pagmadulam et al., 2018; Yao et al., 2009; Yu et al., 2007), and Europe 
(Amdouni et al., 2019; Bărburaș et al., 2019; Klun et al., 2019; Villagra-Blanco et al., 2018). Studies in Latin American countries have been carried out in Argentina (Moore et al., 2014), Brazil (da Silva et al., 2017; de Magalhães et al., 2014; GarcíaMelo et al., 2009), Ecuador (Changoluisa et al., 2019), Peru (Serrano-Martínez et al., 2019), and Venezuela (Lista-Alves et al., 2006). However, in Colombia, information about the status of neosporosis status is scarce, and its transmission dynamics are uncertain.

Some reports have indicated a highly heterogeneous seroprevalence throughout Colombian regions with different cattle production purposes, i.e., 33\% reported for the department of Córdoba (Cardona et al., 2015) and 78\% for Caquetá (Motta-Giraldo et al., 2012), where livestock production is mostly for beef; and 54\% for Cundinamarca, 28,3\% for Antioquia (Llano et al., 2018), and 64\% and 52\% for Boyacá (Cruz-Estupiñán et al., 2019; Pulido-Medellín et al., 2016), where production mainly concerns milk. According to these reports, Boyacá has the second highest N. caninum seroprevalence in Colombia, and one of the highest for the entire Andean region.

Serology is the most commonly used method for diagnosing neosporosis in live animals (Dubey et al., 2007), but assays can be limited by false-negative results in early or chronic cases of infection (Yao et al., 2009) because of specific antibody (Ab) fluctuation sometimes coming below serological test detection limits (Álvarez-García et al., 2003). PCR-based methods have the ability to amplify $N$. caninum DNA in adult and aborted fetus tissues, as well as and in body fluids (blood, milk, and semen) (Collantes-Fernández et al., 2002; Ferre et al., 2005; Yao et al., 2009).

$N$. caninum DNA detection offers valuable information about infection, even in the absence of Abs (McInnes et al., 2006; Ramos et al., 2017) and co-infection (Li et al., 2014). Besides, it enables studying the genetic diversity and phylogenetic relationships of $N$. caninum from multiple hosts and geographical origins (Amdouni et al., 2018; Li et al., 2014; Nardoni et al., 2019; Rocchigiani et al., 2017). It has been used for the direct demonstration of parasite DNA in tissues and body fluids such as peripheral blood (Okeoma et al., 2004; Yao et al., 2009), serum (Bărburaș et al., 2019; Mclnnes et al., 2006), and semen (Amdouni et al., 2019; Ferre et al., 2005).

The $N_{C}-5$ gene has been widely validated and used for the detection of $N$. caninum through PCR because it is specific for the parasite, and its sequence is repeated several times in the genome (Okeoma et al., 2004; Okeoma et al., 2004; Müller et al., 1996; Yao et al., 2009).

According to the Colombian livestock census of 2017, the dairy industry produces $24,3 \%$ of the country's gross domestic product (ICA, 2017). Boyacá is considered the backbone of Colombia's dairy industry, as specialised dairy systems are usually located in the colder climates of central and western provinces (Gobernación de Boyacá, 2019).

Although the region of Boyacá is one of the most relevant for the dairy industry in Colombia, the knowledge about active $N$. caninum infection of dairy cattle remains poor, due to the fact that the area has been understudied. Nested PCR and sequencing for the $\mathrm{N}_{\mathrm{C}}$-5 single copy marker were used on samples collected from three relevant dairy farming areas located near the municipalities of Paipa, Toca, and Tuta in Boyacá's central province to support evidence regarding $N$. caninum infection in the peripheral blood of dairy cattle.

\section{Materials and methods}

\section{Animals and study sites}

The study involved a sample of 170 non-pregnant cows that were 15 months and older, distributed in eight dairy herds from the municipalities of Paipa $(n=50)$, Toca $(n=50)$, and Tuta $(n=70)$ in Boyacá's central province (Figure 1). Dairy herds were selected according to the number of productive heads of cattle (more than 30) that had recent abortions according to owners. 


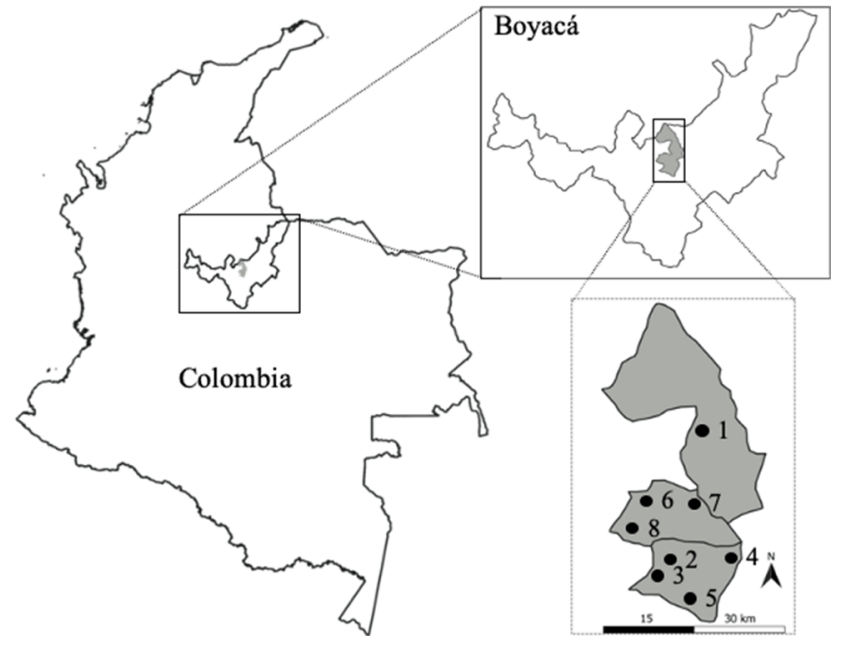

Figure 1. Map of Colombia showing the department of Boyacá and the municipalities of Paipa, Tota, and Toca, where the animals were sampled (Table 1 gives herd numbers for each municipality).

Source: Authors.

\section{Sample collection and DNA extraction}

Between March and October of 2018, whole blood samples were collected from the coccygeal vein of each animal and placed into sterile tubes containing ethylenediaminetraacetic acid (EDTA). Samples were transported in an ice box and immediately transferred to the laboratory, where they were stored at $-20{ }^{\circ} \mathrm{C}$ until DNA extraction and processing. Genomic DNA was extracted from $200 \mu \mathrm{l}$ of blood from each sample (after previous spinning for 2 min at 3000 rpm) using the RealiPrep Blood gDNA Miniprep System (Promega), according to the manufacturer's instructions. DNA integrity was checked on $2 \%$ agarose gel, stained with ethidium bromide and quantified using an Epoch Microplate Spectrophotometer (BioTek). A pGEM-T easy vector (Promega) containing an $\mathrm{Nc}_{\mathrm{C}-5}$ region $350 \mathrm{bp}$ fragment amplified from the $N$. caninum Bahía strain (Ramos et al., 2017) was serially 10-fold diluted in sterile human blood (ranging from $10^{-1}$ to $10^{-4} \mathrm{ng}$ ) and extracted using the RealiPrep Blood gDNA Miniprep System (Promega) as a control for further molecular procedures and the primary PCR detection limit.

\section{Nested PCR and sequencing}

N. caninum PCR reactions were performed in duplicate on all samples. Samples were considered positive if a positive nested PCR product was obtained in at least one of the two rounds. Nc-5 350 bp fragment was amplified using the previously reported Np21+ (5'-CCCAGTGCGTCCAATCCTGTAAC-3') and Np6+ outer primers (5'-CTCGCCAGTCAACCTACGTCTTCT-3') (Müller et al., 1996). Inner primers Np9 (5'-GTTGCTCTGCTGACGTGTCGTTG-3') and Np10 (5'-CGAGAGTTCAGTGTTCTGTGTTGAG-3') were used for nested amplification of a 220 bp fragment, according to what was reported elsewhere (Mclnnes et al., 2006). Each PCR reaction was carried out in a $30 \mu \mathrm{l}$ volume containing $2 \mu \mathrm{l}$ template DNA $(\sim 40$ $\mathrm{ng} / \mu \mathrm{l})$ for the primary PCR and 1,5 $\mu \mathrm{l}$ amplicon for secondary PCR, 1X PCR buffer, 0,2 mM dNTP, 0,5 $\mu \mathrm{M}$ of each primer, $2 \mathrm{mM} \mathrm{MgCl}$, and 1,25 $\mathrm{U}$ Taq DNA polymerase (ExcelTaq, SMOBIO Technology, Inc.). The conditions for both PCR reactions were initial denaturation at $94{ }^{\circ} \mathrm{C}$ for $4 \mathrm{~min}$, followed by 40 cycles of denaturation at $94{ }^{\circ} \mathrm{C}$ for $30 \mathrm{~s}$, annealing at $53{ }^{\circ} \mathrm{C}$ for $30 \mathrm{~s}$, and extension at $72{ }^{\circ} \mathrm{C}$ for 30 $\mathrm{s}$, with a final extension at $72{ }^{\circ} \mathrm{C}$ for $5 \mathrm{~min}$. A negative control (Human DNA) and a positive control (plasmid) were also included in both primary and secondary reactions.

Nested PCR products were visualised on $2 \%$ agarose gel and stained with ethidium bromide. Nc5-PCR amplicon products from four randomly selected individuals and plasmid DNA were sent to Macrogen Inc. in Korea to be purified and sequenced in both directions.

\section{Nc-5 sequence analysis}

Partial Nc-5 forward and reverse sequences were adjusted and aligned to obtain a consensus sequence for each individual; multiple sequences were aligned using ClustalX default parameters (Thompson et al., 1997) and kept in BioEdit v.7.0.9.0 (Hall, 1999). Partial Nc-5 sequences were compared to 
available conspecific sequences from several hosts and geographical origins obtained from GenBank (Table 1). MEGA v10.1.7 (Kumar et al., 2018) was used for calculating K2p-based matrix genetic distances, and the UPGMA-based algorithm was used for drawing heatmaps in $\mathrm{R}$ ( $\mathrm{v} 1.0 .12)$.

\section{RESULTS}

\section{Plasmid Nc-5 and N. caninum DNA detection}

Initial Nc-5 plasmid concentration was $4 \mathrm{ng} / \mu \mathrm{l}$ DNA, and detectable amplification was observed until $10^{-3} \mathrm{ng}(0,004 \mathrm{ng} / \mu \mathrm{l})$ dilution for outer primers (Figure 2A). The qualitative detection limit of N. caninum DNA was $\sim 64$ parasites per volume of blood analyzed $(200 \mu \mathrm{l})$, based on N. caninum's genome size, i.e., $61 \mathrm{Mb}$ (Reid et al., 2012), and according to interconvertible estimation from DNA picograms to base pairs (where $1 \mathrm{Mb}=$ $1,022 \times 10^{-3} \mathrm{pg}$ ), as reported elsewhere (Dolezel et al., 2003).

A total 23 out of 170 samples tested had a $\sim 220$ bp amplicon after inner-PCR (Figure 2B); ten were from Paipa, seven from Toca, and six from Tuta. The 23 cows that tested positive through nested PCR were over 30 months of age. However, in the range of 15 to 29 months old, $N$. caninum
DNA was not detected. The prevalence of parasite DNA in blood was 13,5\% (23/170; 95\% C.I. $7-18)$, ranging from $6,2 \%$ in herd 3 to $37,5 \%$ in herd 2 (both from Toca). Nevertheless, no N. caninum DNA was found in herd 5 of Toca and herd 7 of Tuta (Table 1).

\section{Comparing N. caninum Nc-5 sequences}

Partial Nc-5 from four randomly selected samples was compared to plasmid and an available sequence data for the $N_{c}-5$ gene (GenBank accession no. X84238) (Figure 3). The plasmid sequence was almost identical to the reference sequence. Sequences obtained from Paipa and Tuta showed clear differences against the reference sequence and plasmid, as well as between them (Figure 3). Colombian samples shared two nucleotide substitutions in positions 751 and 784, although eight indels were only observed in the Paipa03 sample (Figure 3). Distance-based heatmaps including $N_{c}-5$ publicly available sequences showed that most of the included sequences were roughly similar, ranking from 0 to 0,1 , except for some pig and bird sequences from China, which had values above 0,15 (Figure 4).

Colombian N. caninum Nc-5 sequences had slight differences, and no conclusive divergence

Table 1. N. caninum-DNA origin, number of samples analyzed and prevalence in blood from herds in Boyacá,

Colombia (C.I. is the confidence interval)

\begin{tabular}{|c|c|c|c|c|c|}
\hline Locality & $\begin{array}{l}\text { Number in } \\
\text { Figure } 1\end{array}$ & $\begin{array}{l}\text { Animals } \\
\text { examined }\end{array}$ & PCR positive & Prevalence (\%) & 95\% C.I. \\
\hline Paipa & 1 & 50 & 10 & 20 & $10.5-34.1$ \\
\hline \multirow[t]{4}{*}{ Toca } & 2 & 8 & 3 & 37.5 & $10.2-74$ \\
\hline & 3 & 16 & 1 & 6.2 & $4.9-46.3$ \\
\hline & 4 & 13 & 3 & 23.1 & $6.1-54$ \\
\hline & 5 & 13 & 0 & 0 & 0 \\
\hline \multirow[t]{3}{*}{ Tuta } & 6 & 17 & 2 & 11.8 & $2-37.7$ \\
\hline & 7 & 20 & 0 & 0 & 0 \\
\hline & 8 & 33 & 4 & 12 & $3.9-29$ \\
\hline Total & & 170 & 23 & 13.5 & $7-18$ \\
\hline
\end{tabular}

Source: Authors 
(A)

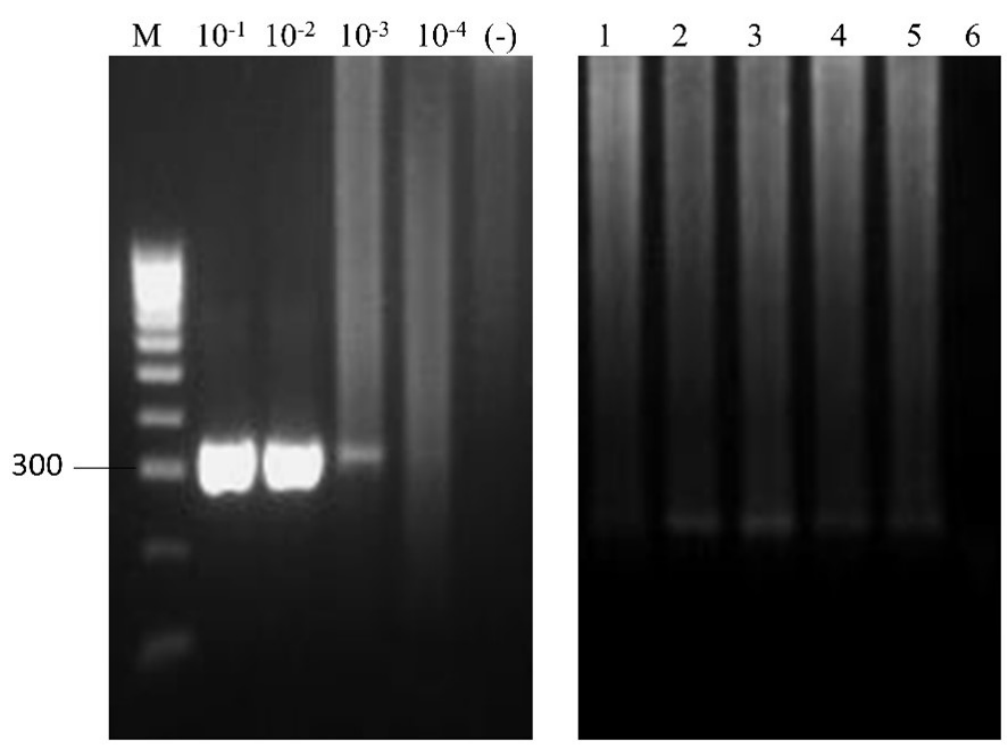

Figure 2. Electrophoresis gel for nested-PCR in serially diluted plasmid containing N. caninum Nc-5 region. A) outer PCR amplification using Np21+ and Np6+ primers; Lane M: DNA marker (100 bp ladder); 10-fold serial dilutions of $N$. caninum plasmid DNA $\left(10^{-1}\right.$ to $\left.10^{-4} \mathrm{ng}\right)$; Lane (-): negative control. B) N. caninum-DNA amplification by nested PCR using Np9 and Np10 inner primers from cow blood; Lane 1: positive control (plasmid DNA 10-3 ng), Lanes 2-5: samples from Paipa and Tuta; Lane 6: negative control.

Source: Authors

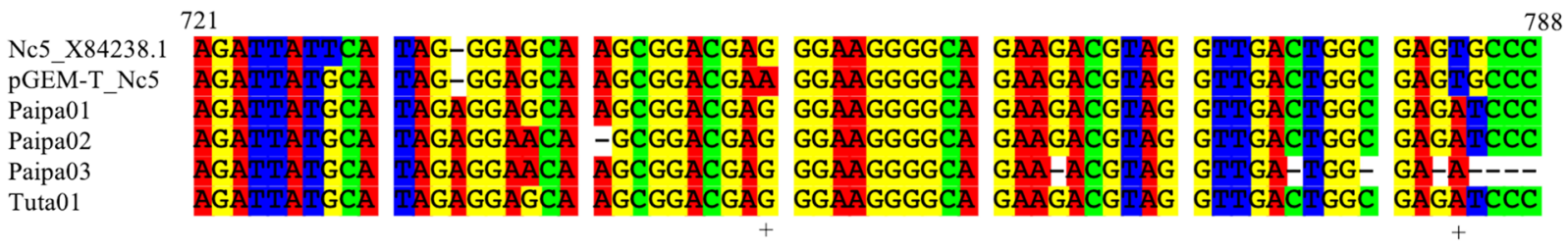

Figure 3. Multiple alignment of $N$. caninum samples partial $N_{c}-5$ sequences, plasmid, and the species-specific DNA probe sequence in GenBank (code X84238). Numbers indicate relative positions, and the (+) symbol indicates shared nucleotide substitutions for Colombian samples.

Source: Authors

could be observed within the main cluster that included most sequences from diverse hosts and countries worldwide (Figure 4). Due to the short fragments used on the study and the limited $N_{C}-5$ information, no phylogenetic or phylogeographic assumptions could be made; instead, further studies are needed which must include additional genetic and biological samples.

\section{DISCUSSION}

Neosporosis is thought to involve low parasitaemia, mostly during non-gestational periods. However, some reports for parasites circulating in blood and other body fluids have increasingly become available in scientific publications (Bărburaș et al., 2019; Dubey et al., 2007; Ferre et al., 2005; Yao 


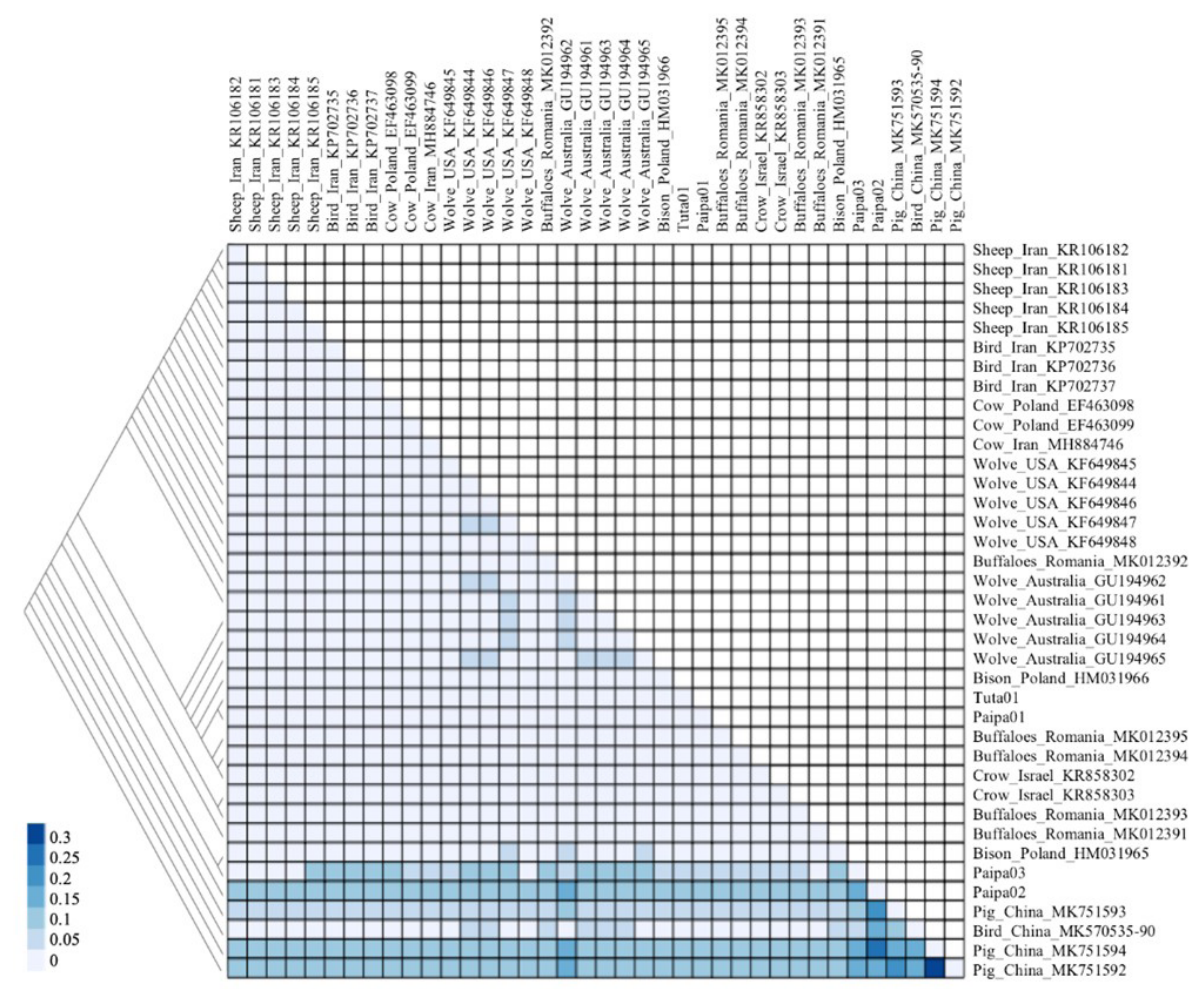

Figure 4. Distance-based cluster and heatmaps for N. caninum NC-5 partial sequences from different hosts and regions worldwide (details in Table S1)

Source: Authors

Table 2. Origin and access codes of Neospora caninum Nc-5 sequences used in the K2p-based distance analysis.

\begin{tabular}{lll}
\hline Country & Biological origin & Accession number \\
\hline Argentina & Goat & MG973171-72 \\
Australia & Wolf & GU194961-65 \\
China & Bird & MK570535-90 \\
& Pig & MK751592-94 \\
Iran & Sheep & KR106181-85 \\
& Bird & KP702735-37 \\
& Dog & KY124528-29 \\
& Cat & KY124530-31 \\
Israel & Cow & MH884746-47 \\
Poland & Crow & KR858302-03 \\
& Bison & HM031965-66 \\
Romania & Cow & EF463098-99 \\
United States & Buffaloes & MK012391-95 \\
\hline
\end{tabular}

Source: Authors 
et al., 2009). This study has explored and revealed, for the first time, N. caninum in peripheral blood of non-pregnant cattle in Colombia.

$N$. caninum in blood could indicate two scenarios: evidence of acute infection involving tachyzoites circulating in the blood flow, or latent infection involving released bradyzoites differentiating into circulating tachyzoites to form new cysts (Okeoma et al., 2004; Yao et al., 2009). The PCR-based method used here did not support either scenario. However, qualitative analysis of our data indicated that the samples contained at least 64 parasites per volume of peripheral blood analyzed $(200 \mu \mathrm{l})$. This would suggest that $N$. caninum parasitaemia was higher than what was initially thought, and this highlighted the need for developing more sensitive molecular-based methods for neosporosis diagnosis and surveillance.

Previous studies have found 10 parasites $/ \mathrm{ml}$ in infected bull semen. However, this was different from what was observed in cow blood, as well as between animals (Ferre et al., 2005). Variable parasitaemia was suggested because $N$. caninum DNA was found in cell fractions due to blood providing a tachyzoite transport medium between host tissues (Okeoma et al., 2004). Identifying parasite DNA in seropositive cattle blood samples was thus intermittent (Collantes-Fernández et al., 2002), which indicates fluctuating parasitaemia as time elapsed, possibly due to immunological action, few circulating parasites, or a short in-host period (Ferre et al., 2005; Yao et al., 2009). We would thus suggest that the heterogeneous prevalence estimated for herds responds to the samples' parasitaemia dynamics, as well as other extrinsic factors.

The loop-mediated isothermal amplificationbased (LAMP) method has recently been suggested for detecting $N$. caninum DNA in fetal tissue from bovine abortion, as well as in canine feces (Ramos et al., 2017). The LAMP technique is ideal in future research to test this approach on peripheral blood, given that it could offer valuable information for the timely management of infection, thereby replacing post-mortem diagnosis.
Results gave $13,5 \%$ overall parasite DNA prevalence (95\% C.I. $7-18)$ in dairy cattle in six out of eight herds sampled from the municipalities of Paipa, Tuta, and Toca in Boyacá. Age was found to be an important factor that influences seroprevalence values, as seropositivity has been seen to increase with it (Dubey et al., 2007). N. caninum DNA was detected here in 23 cows over 30 months of age. This finding suggests that there is not enough evidence of recent displacement or passive transportation from other possible endemic zones.

Active neosporosis infection can be assumed in Boyacá livestock. Further genetic-based studies concerning neosporosis transmission epidemiological dynamics in this area are still needed to provide opportune evidence to better design infection surveillance strategies.

Previous studies in Colombia have indicated that neosporosis infection in cattle is heterogeneous and very high in some places; a 54\% seroprevalence has been reported in Bogotá and the department of Nariño (Zambrano et al., 2001), 78\% in Caquetá (Motta-Giraldo et al., 2012), 33\% in Córdoba (Cardona et al., 2015), and 64\% and $52 \%$ in Boyacá (Cruz-Estupiñán et al., 2019; Pulido-Medellín et al., 2016). This study recorded 6,2 to $37,5 \%$ of $N$. caninum prevalence ranking in several herds from Boyacá (Table 1), which indicates variable infection dynamics on both micro (herd) and regional (departments) scales. This picture supposes that transmission scenarios are driven by local factors involved in heterogeneous biological and epidemiological traits (namely immunological status, intermediate hosts, owner practices, and parasite diversity) which are yet to be further defined.

Several studies have been aimed at understanding $N$. caninum genetic diversity regarding different geographical and host-related origins. Internal transcribed spacer 1 (ITS1) sequence analysis has suggested moderate to high differentiation among N. caninum, isolates from different regions, and different biological origins (Gondim et al., 2004). 
Similar results were found when microsatellite markers were analysed in several populations from American and European countries (Regidor-Cerrillo et al., 201 ). This study compared four Colombian $N$. caninum partial $N_{c}-5$ sequences, thus constituting initial evidence of potentially high genetic differences between them, as well as those from GenBank (Table 2).

Although limited phylogenetic information was available for the $\mathrm{N}_{\mathrm{c}}-5$ fragment used, a genetic distance of more than $10 \%$ was identified between sequences analysed from Paipa and Toca, and non-conclusive genetic clustering was observed within the entire dataset. This would suggest remarkable genetic diversity regarding $N$. caninum strains circulating in Colombia. Further population and phylogeographic studies about Colombian $N$. caninum must be carried out to supply additional information about the evolution and biological traits involved in neosporosis-related epidemiological dynamics.

\section{CONCLUSIONS}

This is the first report of PCR-based identification of $N$. caninum in dairy cattle blood in Colombia, and it indicated active infection in livestock from Boyacá. Further studies about the molecular detection of $N$. caninum in cattle peripheral blood are essential (such as those considering more sensitive PCR-based approaches, i.e. loop-mediated isothermal amplification) for the early diagnosis of neosporosis, as well as introducing more effective cattle/dairy farming-related epidemiological surveillance strategies in Colombia.

\section{References}

Álvarez-García, G., Collantes-Fernández, E., Costas, E., Rebordosa, X., Ortega-Mora, L. M. (2003). Influence of age and purpose for testing on the cut-off selection of serological methods in bovine neosporosis. Veterinary Research, 34(3), 341-352. https:// doi.org/10.1051/vetres:2003009
Amdouni, Y., Rjeibi, M. R., Awadi, S., Rekik, M., Gharbi M. (2018). First detection and molecular identification of Neospora caninum from naturally infected cattle and sheep in North Africa. Transboundary and Emerging Diseases, 65(4), 976-982. https://doi. org/10.1111/tbed.12828

Amdouni, Y., Rouatbi, M., Lassoued, N., Rekik, M., Gharbi, M. (2019). Neospora caninum Natural Infection in Tunisian Rams: Serological Study and Molecular Identification of Infection in Semen. Acta Parasitologica, 64, 821-828. https://doi. org/10.2478/s11686-019-00105-0

Bărburaș, D., Györke, A., Ionică, A. M., Bărburaș, R., Mircean, V., Cozma, V. (2019). Evidence of Neospora caninum infection in buffaloes (Bubalus bubalis) from Northwestern Romania. Parasitolology Research, 118, 1667-1671. https://doi.org/10.1007/ s00436-019-06263-4

Cardona, J. A., Martínez, Y., Betancur, C. A. (2015). Seroepidemiología de hembras bovinas naturalmente infectadas por Neospora caninum en Córdoba, Colombia. Revista UDCA Actualidad \& Divulgación Científica, 18(2), 401-408. https://doi. org/10.31910/rudca.v18.n2.2015.166

Changoluisa, D., Rivera-Olivero, I. A., Echeverria, G., Garcia-Bereguiain, M. A., de Waard J. H., Applied Microbiology group of the School of Biological Sciences and Engineering at Yachay University (2019). Serology for Neosporosis, Q fever and Brucellosis to assess the cause of abortion in two dairy cattle herds in Ecuador. BMC Veterinary Research, 15, 194. https://doi.org/10.1186/ s12917-019-1924-7

Collantes-Fernández, E., Zaballos, Á., Álvarez-García, G., Ortega-Mora, L. M. (2002). Quantitative detection of Neospora caninum in bovine aborted fetuses and experimentally infected mice by real-time PCR. Journal of Clinical Microbiology, 40(4), 1194-1198. https://doi.org/10.1128/jcm.40.4.1194-1198.2002

Cruz-Estupiñán, S., Díaz-Anaya, A., Bulla-Castañeda, D., García-Corredor, D., Pulido-Medellín, M. (2019). Diagnóstico Serológico de Neospora caninum en vacas del municipio de Tuta, Boyacá. Revista de la Facultad de Medicina Veterinaria y Zootecnia, 
66(3), 197-207. https://doi.org/10.15446/rfmvz. v66n3.84256

da Silva, J. B., Nicolino, R. R., Fagundes, G. M., dos Anjos Bomjardim, H., dos Santos Belo Reis, A., da Silva Lima, D. H., Oliveira, C. M. C., Barbosa, J. D., da Fonseca, A. H. (2017). Serological survey of Neospora caninum and Toxoplasma gondii in cattle (Bos indicus) and water buffaloes (Bubalus bubalis) in ten provinces of Brazil. Comparative Immunology, Microbiology and Infectious Diseases, 52, 3035. https://doi.org/10.1016/j.cimid.2017.05.005

de Magalhães, V. C., de Oliveira, U. V., Costa, S. C., Santos, I. A., Pereira, M. J., Munhoz A. D. (2014). Transmission paths of Neospora caninum in a dairy herd of crossbred cattle in the northeast of Brazil. Veterinary Parasitology, 202(3-4), 257-264. https:// doi.org/10.1016/j.vetpar.2014.01.018

Dolezel, J., Bartos, J., Voglmayr, H., Greilhuber, J. (2003). Nuclear DNA content and genome size of trout and human. Journal of Qualitative Cell SCience: Cytometry, Part A, 51A(2), 127-129. https:// doi.org/10.1002/cyto.a.10013

Dubey, J. P. (2003). Review of Neospora caninum and neosporosis in animals. The Korean Journal of Parasitology, 41(1), 1. https://doi.org/10.3347/ kjp.2003.41.1.1

Dubey, J. P., Schares, G. (2006). Diagnosis of bovine neosporosis. Veterinary Parasitology, 140(1-2), 1-34. https://doi.org/10.1016/j.vetpar.2006.03.035

Dubey, J. P., Schares, G., Ortega-Mora, L. M. (2007). Epidemiology and control of neosporosis and Neospora caninum. Clinical Microbiolology Reviews, 20(2), 323-367. https://doi.org/10.1128/CMR.00031-06

Ferre, I., Aduriz, G., del Pozo, I., Regidor-Cerrillo, J., Atxaerandio, R., Collantes-Fernández, E., Hurtado, A., Ugarte-Garagalza, C., Ortega-Mora L. M. (2005). Detection of Neospora caninum in the semen and blood of naturally infected bulls. Theriogenology, 63(5),1504-1518. https://doi.org/10.1016/j. theriogenology.2004.07.002

García-Melo, D. P., Regidor-Cerrillo, J., Ortega-Mora, L. M., Collantes-Fernández, E., de Oliveira, V. S. F., de Oliveira, M. A. P., da Silva A. C. (2009). Isolation and biological characterisation of a new isolate of
Neospora caninum from an asymptomatic calf in brazil. Acta Parasitologica, 54(2), 180-185. https:// doi.org/10.2478/s11686-009-0018-2

Gondim, L. F., Laski, P., Gao, L., McAllister, M. M. (2004). Variation of the internal transcribed spacer 1 sequence within individual strains and among different strains of Neospora caninum. Journal of Parasitology, 90(1), 119-123. https://doi.org/10.1645/ GE-134R

Hall, T. A. (1999). BioEdit: a user-friendly biological sequence alignment editor and analysis program for Windows 95/98/NT. Nucleic Acids Symposium Series, 41, 95-98.

Instituto Colombiano Agropecuario (ICA) (2017). Censo Pecuario 2017. https://www.ica.gov.co/areas/ pecuaria/servicios/epidemiologiaveterinaria/censos-2016/censo-2017.aspx

Klun, I., Ćirković, V., Maletić, M., Bradonjić, S., Djurković-Djaković, O. (2019). Seroprevalence of Neospora caninum infection and associated risk factors in dairy cattle in Serbia. Parasitology Research, 118, 1875-1883. https://doi.org/10.1007/ s00436-019-06307-9

Kumar, S., Stecher, G., Li, M., Knyaz, C., Tamura, K. (2018). MEGA X: Molecular Evolutionary Genetics Analysis across Computing Platforms. Molecular Biology and Evolution, 35(6), 1547-1549. https://doi. org/10.1093/molbev/msy096

Li, J., He, P., Yu, Y., Du, L., Gong, P., Zhang, G., Zhang, X. (2014). Detection of Neospora caninum-DNA in feces collected from dogs in Shenyang (China) and ITS1 phylogenetic analysis. Veterinary Parasitology, 205(1-2), 361-364. https://doi.org/10.1016/j. vetpar.2014.06.036

Lista-Alves, D., Palomares-Naveda, R., García, F., Obando, C., Arrieta, D., Hoet, A. E. (2006). Serological evidence of Neospora caninum in dual-purpose cattle herds in Venezuela. Veterinary Parasitology, 13(3-4), 347-349. https://doi.org/10.1016/j. vetpar.2005.11.027

Llano, H. A. B., Guimarães, M. S., Soares, R. M., Polo, G., da Silva, A. C. (2018). Seroprevalence and risk factors for Neospora caninum infection in cattle from the eastern Antioquia, Colombia. Veterinary and 
Animal Science, 6, 69-74. https://doi.org/10.1016/j. vas.2018.03.001

Mclnnes, L. M., Ryan, U. M., O'Handley, R., Sager, H., Forshaw, D., Palmer, D. G. (2006). Diagnostic significance of Neospora caninum DNA detected by PCR in cattle serum. Veterinary Parasitology, 142(3-4), 207-213. https://doi.org/10.1016/j. vetpar.2006.07.013

Moore, D. P., Konrad, J. L., San Martino, S., Reichel, M. P., Cano, D. B., Méndez, S., Späth, E. J., Odeón, A. C., Crudeli, G., Campero C. M. (2014). Neospora caninum serostatus is affected by age and species variables in cohabiting water buffaloes and beef cattle. Veterinary Parasitology, 203(3-4), 259-263. https://doi.org/10.1016/j.vetpar.2014.04.011

Motta-Giraldo, J., Waltero-García, I., Abeledo, M., Fernández, O. (2012). Estudio retrospectivo de agentes infecciosos que afectan la reproducción bovina en el departamento del Caquetá, Colombia. Revista de Salud Animal, 34(3), 159-164.

Müller, N., Zimmermann, V., Hentrich, B., Gottstein, B. (1996). Diagnosis of Neospora caninum and Toxoplasma gondii infection by PCR and DNA hybridization immunoassay. Journal of Clinical Microbiology, 34(11), 2850-2852. https://doi. org/10.1128/JCM.34.11.2850-2852.1996

Nardoni, S., Poli, A., Varvaro, I., Rocchigiani, G., Ceccherelli, R., Mancianti, F. (2019). Detection of Neospora Caninum DNA in Wild Birds from Italy. Pathogens, 8(4), 202. https://doi.org/10.3390/ pathogens8040202

Okeoma, C. M., Williamson, N. B., Pomroy, W. E., Stowell, K. M., Gillespie, L. (2004). The use of PCR to detect Neospora caninum DNA in the blood of naturally infected cows. Veterinary Parasitology, 122(4), 307-315., https://doi.org/10.1016/j. vetpar.2004.06.001

Pagmadulam, B., Myagmarsuren, P., Fereig, R. M., Igarashi, M., Yokoyama, N., Battsetseg, B., Nishikawa, Y. (2018). Seroprevalence of Toxoplasma gondii and Neospora caninum infections in cattle in Mongolia. Veterinary Parasitology: Regional Studies and Reports, 14, 11-17. https://doi.org/10.1016/j. vprsr.2018.08.001
Gobernación de Boyacá (Secretaría de Agricultura) (2019). Plan Departamental de Extension Agropecuaria. https://www.minagricultura.gov.co/ministerio/direcciones/Documents/PDEA \%27s\%20 Aprobados/PDEA\%20Boyac\%C3\%A1.pdf

Pulido-Medellín, M. O., García-Corredor, D. J., VargasAbella, J. C. (2016). Seroprevalencia de Neospora caninum en un Hato Lechero de Boyacá, Colombia. Revista de Investigaciones Veterinarias del Perú, 27(2), 355-362. https://doi.org/10.15381/ rivep.v27i2.11658

Ramos, A. E., Muñoz, M., Cortés-Vecino, J. A., Barato, P., Patarroyo M. A. (2017). A novel loop-mediated isothermal amplification-based test for detecting Neospora caninum DNA. Parasites \& Vectors, 10(1), 590. https://doi.org/10.1186/s13071-017-2549-y

Regidor-Cerrillo, J., Díez-Fuertes, F., García-Culebras, A., Moore, D. P., González-Warleta, M., Cuevas, C., Schares, G., Katzer, F., Pedraza-Díaz, S., Mezo, M. (2013). Genetic diversity and geographic population structure of bovine Neospora caninum determined by microsatellite genotyping analysis. PLOS One 8(8), e72678. https://doi.org/10.1371/journal. pone. 0072678

Reid, A. J., Vermont, S. J., Cotton, J. A., Harris, D., HillCawthorne, G. A., Könen-Waisman, S., Latham, S. M., Mourier, T., Norton, R., Quail, M. A. (2012). Comparative genomics of the apicomplexan parasites Toxoplasma gondii and Neospora caninum: Coccidia differing in host range and transmission strategy. PLoS Pathogens, 8(3), e1002567. https:// doi.org/10.1371/journal.ppat.1002567

Rocchigiani, G., Poli, A., Nardoni, S., Papini, R., Mancianti, F. (2017). Neospora caninum in Wild Waterfowl: Occurrence of Parasite DNA and Low Antibody Titers. Journal of Parasitology, 103, 142145. https://doi.org/10.1645/16-34

Serrano-Martínez, M. E., Cisterna, C. A. B., Romero, R. C. E., Huacho, M. A. Q., Bermabé, A. M., Albornoz, L. A. L. (2019). Evaluation of abortions spontaneously induced by Neospora caninum and risk factors in dairy cattle from Lima, Perú. Revista Brasileira de Parasitologia Veterinária, 28, 215-220. https://doi.org/10.1590/S1984-29612019026 
Thompson, J. D., Gibson, T. J., Plewniak, F., Jeanmougin, F., Higgins, D. G. (1997). The ClustalX windows interface: Xexible strategies for multiple sequence alignment aided by quality analysis tools. Nucleic Acids Research, 24, 4876-4882. https:// doi.org/10.1093/nar/25.24.4876

Villagra-Blanco, R., Angelova, L., Conze, T., Schares, G., Bärwald, A., Taubert, A., Hermosilla, C., Wehrend, A. (2018). Seroprevalence of Neospora caninumspecific antibodies in German breeding bitches. Parasites \& Vectors, 11, 96. https://doi.org/10.1186/ s13071-018-2683-1

Yao, L., Yang, N., Liu, Q., Wang, M., Zhang, W., Qian, W., Hu, Y., Ding, J. (2009). Detection of Neospora caninum in aborted bovine fetuses and dam blood samples by nested PCR and ELISA and seroprevalence in Beijing and Tianjin, China. Parasitology, 136(11), 1251-1256. https://doi.org/10.1017/S0031182009990813

Yu, J., Xia, Z., Liu, Q., Liu, J., Ding, J., Zhang, W. (2007). Seroepidemiology of Neospora caninum and Toxoplasma gondii in cattle and water buffaloes (Bubalus bubalis) in the People's Republic of China. Veterinary Parasitology, 143(1), 79-85. https://doi. org/10.1016/j.vetpar.2006.07.031

Zambrano, J., Cotrino, V., Jiménez, C., Romero, M., Guerrero, B. (2001). Evaluación serológica de Neospora caninum en bovinos en Colombia. Revista Acovez, 26, 5-10. 